\section{PENCIRIAN TEMPORAL SKALA KECIL AIR SISA DOMESTIK PERBANDARAN}

\section{SMALL SCALE TEMPORAL CHARACTERISATION OF URBAN DOMESTIC WASTEWATER}

Z. M. Hanafiaha, W. H. M. W. Mohtara*, N. A. Bachi'a, N. A. Abdullaha, M. Z. Abdullaha, T. S. A. Manan ${ }^{b}$, A. Amirc

a Jabatan Kejuruteraan Awam, Fakulti Kejuruteraan dan Alam Bina, Universiti Kebangsaan Malaysia, 43600 UKM Bangi, Selangor, Malaysia

bInstitut Biodiversiti Tropika dan Pembangunan Lestari, Universiti Malaysia Terengganu, 21030 Kuala Nerus, Terengganu, Malaysia

CFakulti Kejuruteraan Awam, Universiti Teknologi, 40450 Shah Alam, Malaysia
Article history

Received

5 March 2021

Received in revised form

28 June 2021

Accepted

4 July 2021

Published online

20 August 2021

*Corresponding author hanna@ukm.edu.my

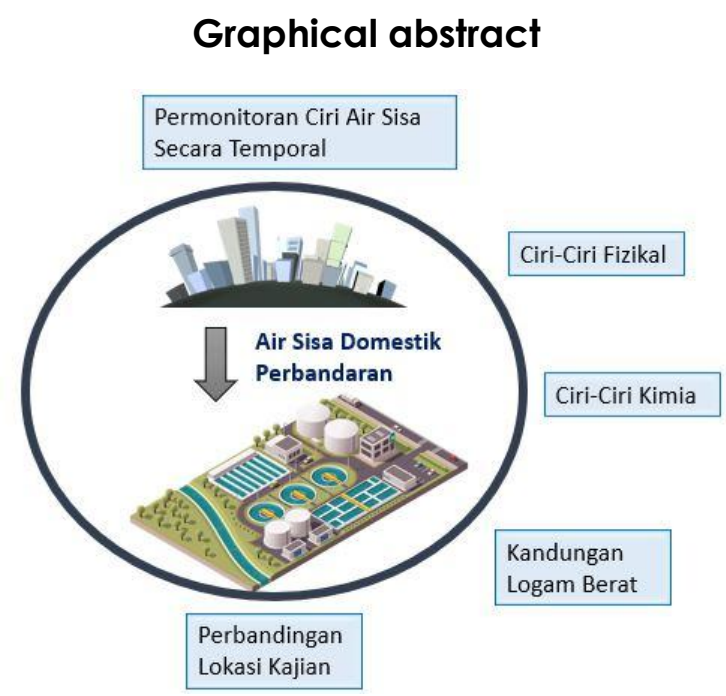

\begin{abstract}
Sewage treatment plants (STP) in Malaysia are designed to treat a load of contaminants according to the level of concentration for chemical oxygen demand (COD) and nitrogen ammonia (NH3-N) of $250 \mathrm{mg} / \mathrm{L}$ and $30 \mathrm{mg} / \mathrm{L}$, respectively. However, studies show that the organic load of Malaysian wastewater is low and even temporarily fluctuates resulting in the low effectiveness of treatment especially in ammonia removal and consequently cause effluents that do not undergo proper treatment to be released into the environment. Therefore, this study aims to identify concentrations of $\mathrm{COD}$ and $\mathrm{NH} 3-\mathrm{N}$ in the influent of urban domestic wastewater along with other physico-chemical characteristics. Two locations of the STP were chosen based on the urban area with different catchment sizes for a population equivalent (PE) 60,000 for the first STP (LRK\#1), and 150,000 for the second STP (LRK\#2). These parameters include $\mathrm{pH}$, temperature, conductivity, turbidity, total suspended solids (TSS), nitrogen nitrate (NO3-N), total Kjeldahl nitrogen (TKN) as well as heavy metals such as Cadmium (Cd), Chromium (Cr), Copper (Cu), Nickel (Ni), Lead (Pb), and Zinc (Zn). The sampling and analysis methods used the guidelines recommended in the American Public Health Association (APHA). The results give the highest average COD concentrations for the LRK\#1 and LRK\#2 are $180.5 \mathrm{mg} / \mathrm{L}$ and 380.9 $\mathrm{mg} / \mathrm{L}$, respectively. The highest NH3-N concentrations were $33.53 \mathrm{mg} / \mathrm{L}$ for LRK\# 1 and $31.63 \mathrm{mg} / \mathrm{L}$ for LRK\#2. Overall, the wastewater physicochemical characteristics of both treatment plants show wastewater in the medium and low concentration categories.
\end{abstract}

Keywords: Sewage Treatment Plant, Influent, Characterisation, Urban Domestic Wastewater 


\begin{abstract}
Abstrak
Loji rawatan kumbahan (LRK) di Malaysia direka bentuk untuk merawat beban pencemar mengikut tahap kepekatan permintaan oksigen kimia (COD) dan nitrogen ammonia (NH3-N) dengan masing-masing berada pada paras $250 \mathrm{mg} / \mathrm{L}$ dan $30 \mathrm{mg} / \mathrm{L}$. Walau bagaimanapun, kajian menunjukkan bahawa beban organik air kumbahan Malaysia adalah lebih rendah, malah secara temporalnya bersifat turun naik mengakibatkan keberkesanan rawatan terutamanya penyingkiran ammonia adalah tidak optimum dan seterusnya menyebabkan efluen yang tidak dirawat dengan sempurna dilepaskan ke alam sekitar. Sehubungan dengan itu, kajian ini dilakukan bertujuan untuk mengenal pasti tahap kepekatan COD dan NH3-N serta ciri fiziko-kimia dalam influen air sisa domestik perbandaran. Dua lokasi kajian yang terletak di kawasan perbandaran telah dipilih dengan ciri saiz tadahan yang berbeza, iaitu LRK pertama (LRK\#1) bagi populasi setara penduduK (PE) 60,000, manakala LRK kedua (LRK\#2) pula bagi 150,000. Parameter kualiti air yang diukur termasuklah $\mathrm{pH}$, suhu, kekonduksian, kekeruhan, jumlah pepejal terampai (TSS), nitrogen nitrat (NO3-N), jumlah nitrogen kjeldahl (TKN), dan logam berat seperti Cadmium (Cd), Kromium (Cr), Tembaga (Cu), Nikel (Ni), Plumbum (Pb), dan Zink (Zn). Kaedah pensampelan dan analisis yang digunakan adalah berdasarkan garis panduan yang dicadangkan oleh American Public Health Association (APHA). Keputusan menunjukkan bahawa kepekatan purata COD tertinggi bagi LRK\# 1 dan LRK\#2 masing-masing $180.5 \mathrm{mg} / \mathrm{L}$ dan 380.9 $\mathrm{mg} / \mathrm{L}$. Kepekatan NH3-N tertinggi ialah $33.53 \mathrm{mg} / \mathrm{L}$ untuk LRK\# 1 dan $31.63 \mathrm{mg} / \mathrm{L}$ untuk LRK\#2. Secara keseluruhannya, ciri fiziko-kimia air sisa bagi kedua-dua loji rawatan menunjukkan air sisa kumbahan berada dalam kategori berkepekatan sederhana dan rendah.

Kata kunci: Loji Rawatan Kumbahan, Influen, Pencirian, Perbandaran, Air Sisa Domestik

(C) 2021 Penerbit UTM Press. All rights reserved
\end{abstract}

\subsection{PENGENALAN}

Air sisa domestik atau air kumbahan merupakan air yang telah terpakai oleh penggunaan aktiviti seharian oleh komuniti seperti dari tandas, dari sinki, cucian pakaian, dan mandian. Pelbagai kajian dan teknologi telah dibangunkan untuk merawat air sisa kumbahan untuk memenuhi piawaian kualiti yang telah ditetapkan sebelum air sisa ini dilepaskan ke badan air bagi memastikannya bukan sahaja tidak membahayakan kesihatan manusia, bahkan juga alam sekitar. Namun begitu, pencemaran air masih meningkat berkadaran seiring dengan peningkatan kepesatan bilangan penduduk dan pembangunan. Pencirian air sisa domestik dari kawasan perbandaran adalah penting bagi mengetahui kandungan dan tahap kepekatan bahan-bahan pencemar tersebut yang menjadikannya sebagai salah satu punca pencemaran air. Hal ini dikatakan demikian kerana ciri awal air sisa domestik yang masuk ke dalam loji rawatan dapat menentukan keberkesanan kaedah rawatan yang dipilih dalam sesuatu reka bentuk loji rawatan kumbahan (LRK) dan seterusnya dapat mengelakkan bahan-bahan pencemar yang tidak dirawat dengan sempurna terlepas ke badan air. Secara umumnya, kualiti air sisa domestik perbandaran diwakili oleh parameter fiziko-kimia seperti nilai $\mathrm{pH}$, permintaan oksigen kimia (COD), nitrogen ammonia $\left(\mathrm{NH}_{3}-\mathrm{N}\right)$, suhu, kekonduksian, kekeruhan, jumlah pepejal terampai (TSS), dan nitrogen nitrat $\left(\mathrm{NO}_{3}-\mathrm{N}\right)$.

Paip pembetungan yang membawa sisa kumbahan perbandaran ke LRK dijangkakan mempunyai kepekatan COD minimum, iaitu 500 $\mathrm{mg} / \mathrm{L}$ berdasarkan nilai reka bentuk sesebuah loji rawatan kumbahan, iaitu Garis Panduan Industri Pembetungan Malaysia (MSIG)[1]. Namun begitu, kepekatan COD terukur yang sebenar dalam influen adalah tidak konsisten dengan kepekatannya yang turun naik, malah boleh mencapai kepekatan serendah $50 \mathrm{mg} / \mathrm{L}$ ketika aliran perlahan [2]. Kepekatan COD yang rendah berpunca daripada beberapa faktor dan antaranya disebabkan oleh penyusupan air ke dalam paip pembetungan ketika hujan sama ada melalui rekahan paip mahupun penutup lurang. Selain itu, air sisa kumbahan di dalam paip pembetungan juga boleh menyusup keluar akibat rekahan pada paip serta tambahan dengan tabiat penggunaan air yang banyak dalam kalangan komuniti menyebabkan ciri air sisa 
kumbahan menjadi cair [3]. Air kumbahan yang berkepekatan rendah ini boleh mempengaruhi keberkesanan rawatan di LRK yang jelas menunjukkan bahawa kebanyakan LRK di Malaysia direka bentuk berasaskan rawatan secara biologi [4].

Sebagai contoh, rawatan air sisa secara dalam penyingkiran ammonia melalui proses nitrifikasi dan dinitrifikasi boleh terjejas disebabkan oleh ciri air sisa yang berkepekatan rendah [5, 6]. Proses dinitrifikasi memerlukan sumber organik daripada air sisa sebagai proses penukaran ion nitrit $\left(\mathrm{NO}^{2-}\right)$ dan ion nitrat $\left(\mathrm{NO}^{3-}\right)$ kepada gas nitrogen $\left(\mathrm{N}_{2}\right)$. Ion $\mathrm{NO}^{2-}$ dan $\mathrm{NO}^{3-}$ yang tidak bertukar menjadi gas nitrogen boleh mengalir keluar ke badan air seperti sungai bersamasama dengan efluen dan seterusnya akan menyebabkan gangguan kepada kualiti air sungai dan juga ekosistem akuatik seperti eutrofikasi sumber air yang akan menyebabkan alga dan tumbuhan di dalam air tumbuh berlebihan dan seterusnya menyebabkan oksigen di dalam air berkurangan yang akhirnya menyebabkan ikan-ikan mati kesan daripada kekurangan oksigen [7]. Selain itu, nitrat dan nitrit juga mempunyai kesan yang tidak baik terhadap kesihatan manusia memandangkan kedua-duanya boleh menyebabkan kerosakan hati dan menyumbang kepada risiko penyakit kanser [8].

Kedudukan loji-loji rawatan yang berada di hulu muka sauk loji rawatan air juga akan memberikan risiko pencemaran kepada air bersih akibat daripada rawatan kumbahan yang tidak sempurna dan seterusnya akan menyebabkan penutupan loji rawatan air. Antara penyakit bawaan air yang biasa dikesan adalah seperti taun, demam kepialu, ciritbirit, dan jangkitan virus seperti Hepatitis A, Rotavirus, dan virus Coxscakie [9]. Kajian kepustakaan menunjukkan kehadiran nitrat dalam air sungai Malaysia [10] dan kepekatan ion ammonium $\left(\mathrm{NH}^{4+}\right)$ yang dikesan dalam badan air berpunca daripada loji rawatan kumbahan [11]. Selain itu, dalam kajian kualiti air efluen yang dilepaskan ke sungai oleh Sabeen (2018) [12] terhadap loji rawatan kumbahan di beberapa loji di Malaysia menunjukkan bahawa kepekatan fosforus (P), $\mathrm{NO}^{2-}$, dan $\mathrm{NO}^{3-}$ melebihi kualiti pelepasan air efluen yang telah ditetapkan.
Kajian kepustakaan terhadap perbandingan parameter fiziko-kimia influen air sisa domestik dari negara Korea, Afrika, Algeria, Zimbabwe, India, Romania, dan Kuwait ditunjukkan menerusi Jadual 1, 2, dan 3. Jadual 1 menunjukkan pengelasan parameter fizikal air sisa, iaitu TSS, kekeruhan, dan suhu. Sementara itu, Jadual 2 pula merupakan perbandingan parameter kimia, iaitu COD, $\mathrm{NH}_{3}-\mathrm{N}$, NO3-N, TKN, ortofosfat, konduktiviti, dan $\mathrm{pH}$ dan seterusnya Jadual 3 menunjukkan kandungan logam berat ( $\mathrm{Cd}, \mathrm{Cr}, \mathrm{Ni}, \mathrm{Pb}, \mathrm{Zn}$, dan $\mathrm{Cu}$ ) yang terkandung dalam influen air sisa domestik bagi negara-negara tersebut yang menunjukkan negara China dan Kuwait mempunyai kepekatan elemen logam berat yang tertinggi.

Perbezaan kandungan dan kekuatan air sisa domestik bergantung pada faktor-faktor seperti lokasi, hujan, jenis pembetungan, luahan industri, diet komuniti setempat, dan saiz tadahan loji rawatan [13]. Dengan mengambil kira faktor-faktor tersebut, pencirian air sisa terhadap sisa kumbahan tempatan adalah penting bagi mengetahui tahap kekuatan air sisa domestik yang sebenar bagi tujuan reka bentuk dan perawatan yang lebih berkesan. Oleh hal yang demikian, objektif kajian untuk kajian ini bermatlamat untuk mengetahui ciri-ciri influen air sisa domestik di kawasan perbandaran tempatan selain mengetahui tahap kekuatan air sisa domestik terkini bagi loji kajian dan seterusnya membuat perbandingan dengan nilai reka bentuk bagi loji kumbahan, iaitu Garis Panduan Industri Pembetungan Malaysia (MSIG).

Jadual 1 Perbandingan parameter fizikal dalam influen air sisa domestik pelbagai negara

\begin{tabular}{cllll}
\hline $\begin{array}{l}\text { Ruju } \\
\text { kan }\end{array}$ & Negara & \multicolumn{3}{c}{ Parameter fizikal } \\
\cline { 3 - 5 } & & $\begin{array}{l}\text { TSS } \\
(\mathbf{m g} / \mathbf{L})\end{array}$ & $\begin{array}{l}\text { Kekeruhan } \\
\text { (NTU) }\end{array}$ & $\begin{array}{l}\text { Suhu } \\
\left({ }^{\circ} \mathbf{C}\right)\end{array}$ \\
\hline$[14]$ & Korea & ND & ND & $18.8 \pm 6$ \\
{$[15]$} & Afrika & ND & $112-580$ & $22-30.1$ \\
{$[16]$} & Algeria & ND & ND & $19.6-26$ \\
{$[17]$} & Zimbabwe & $250 \pm 66$ & ND & ND \\
{$[18]$} & India & $1824.42 \pm 8.46$ & $20.86 \pm 6.82$ & ND \\
{$[19]$} & Romania & ND & ND & ND \\
{$[20]$} & Kuwait & $75-650$ & $\mathrm{ND}$ & $\mathrm{ND}$ \\
\hline${ }^{*} \mathrm{ND}=$ tidak di ukur & & &
\end{tabular}

Jadual 2 Perbandingan parameter kimia dalam influen air sisa domestik pelbagai negara

\begin{tabular}{|c|c|c|c|c|c|c|c|c|}
\hline \multirow{2}{*}{$\begin{array}{l}\text { Rujuk } \\
\text { an }\end{array}$} & \multirow[t]{2}{*}{ Negara } & \multicolumn{7}{|c|}{ Parameter kimia } \\
\hline & & $\begin{array}{l}\text { COD } \\
(\mathrm{mg} / \mathrm{L})\end{array}$ & $\begin{array}{l}\mathrm{NH}_{3}-\mathrm{N} \\
(\mathrm{mg} / \mathrm{L})\end{array}$ & $\begin{array}{l}\mathrm{NO}_{3}-\mathrm{N} \\
(\mathrm{mg} / \mathrm{L})\end{array}$ & $\begin{array}{l}\text { TKN } \\
\text { (mg/L) }\end{array}$ & $\begin{array}{l}\text { Ortofosfat } \\
\text { (mg/L) }\end{array}$ & $\begin{array}{l}\text { Konduktiviti } \\
(\mu \mathrm{S} / \mathrm{cm})\end{array}$ & $\mathrm{pH}$ \\
\hline [14] & Korea & $67.6 \pm 8.6$ & $33.5 \pm 5.2$ & ND & ND & $3.5 \pm 0.3$ & ND & ND \\
\hline [15] & Afrika & $274-329$ & $8-112.5$ & $0.93-48.5$ & ND & $0.06-3.71$ & $2550-3190$ & $7.04-8.77$ \\
\hline [16] & Algeria & $223-691$ & ND & ND & ND & ND & $3980-4550$ & $6.68-7.86$ \\
\hline [17] & Zimbabwe & $527 \pm 15$ & $25.6 \pm 11.2$ & ND & $21.0 \pm 3.0$ & ND & ND & $7.0 \pm 0$ \\
\hline [18] & India & $1420.5 \pm 8.16$ & ND & ND & $84.99 \pm 8.85$ & $124.42 \pm 5.52$ & $2840 \pm 0.21$ & $8.39 \pm 0.19$ \\
\hline [19] & Romania & $150-1160$ & ND & $0-5.0$ & ND & $3.5 \pm 0.3$ & ND & ND \\
\hline [20] & Kuwait & $480-1250$ & $44-100$ & ND & ND & $14-64$ & ND & ND \\
\hline
\end{tabular}


Jadual 3 Perbandingan kandungan logam berat dalam influen air sisa domestik pelbagai negara

\begin{tabular}{llllllll}
\hline Rujukan & Negara & \multicolumn{7}{c}{ Logam berat (mg/L) } \\
\cline { 3 - 7 } & & $\mathbf{C d}$ & $\mathbf{C r}$ & $\mathbf{N i}$ & $\mathbf{P b}$ & $\mathbf{Z n}$ & $\mathbf{C u}$ \\
\hline$[21]$ & Korea & $2.5 \pm 2.1$ & $135 \pm 140$ & $154 \pm 51$ & $38 \pm 19$ & $71 \pm 32$ & $1643 \pm 230$ \\
{$[18]$} & India & $0.64-0.06$ & $0.21-0.02$ & $0.78 \pm 0.08$ & $0.46 \pm 0.04$ & $\mathrm{ND}$ & $3.24 \pm 0.44$ \\
{$[22]$} & China & $170-38.4$ & $317.2 \pm 317.2$ & $523.9 \pm 635$ & $67.7 \pm 71.3$ & $28.4 \pm 27$ & $1754 \pm 2057$ \\
{$[20]$} & Kuwait & 21 & 80 & 700 & 111 & 337 & 2002 \\
\hline
\end{tabular}

\subsection{METADOLOGI}

\subsection{Kawasan Kajian}

Kajian permonitoran ciri-ciri fiziko-kimia air sisa domestik ini telah memilih dua lokasi perbandaran seperti yang ditunjukkan menerusi Rajah 1. Loji rawatan kumbahan pertama (LRK\#1) merupakan loji yang merawat sisa kumbahan bagi penduduk setara (PE) seramai 60,000 dan terletak di kawasan sekitar Lembah Klang. Parameter kimia yang dimonitor ialah COD dan $\mathrm{NH}_{3}-\mathrm{N}$ dalam tempoh 24 jam secara bulanan antara tahun 2019 hingga 2020.

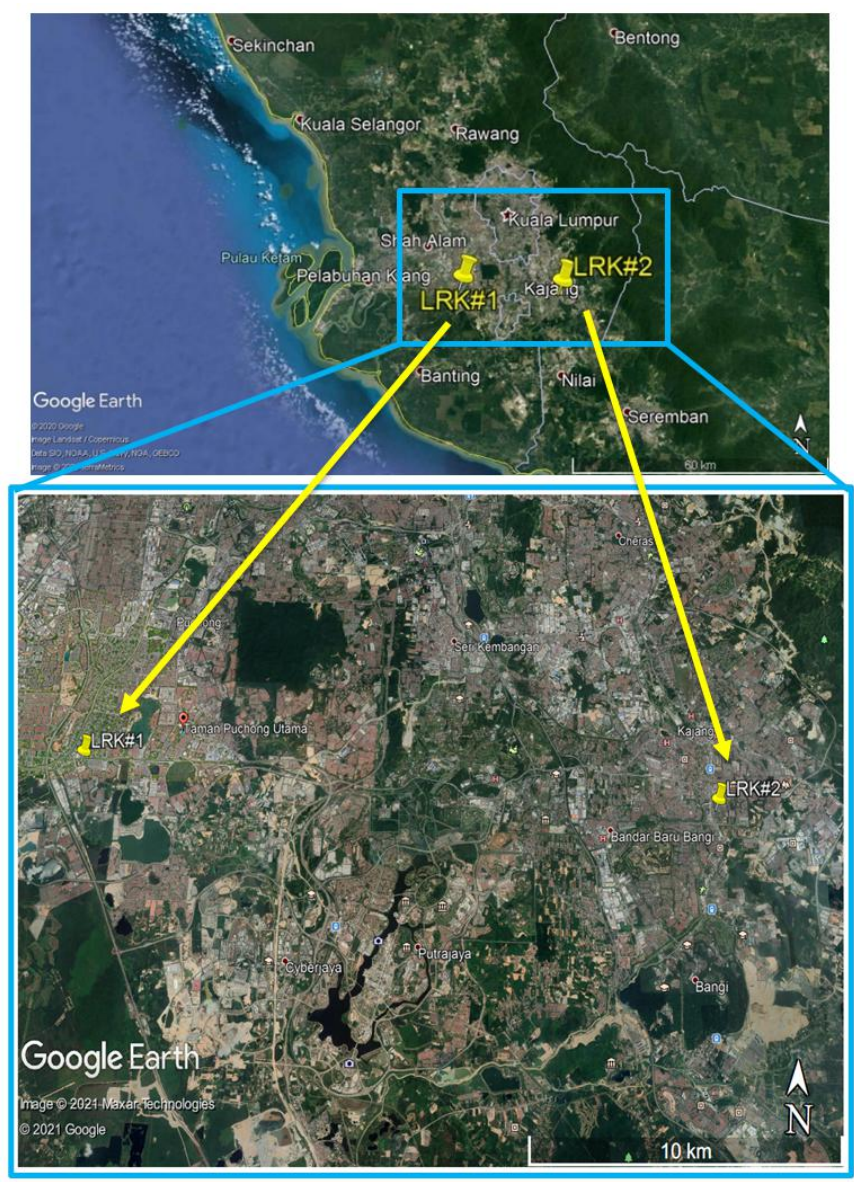

Rajah 1 Lokasi pensampelan di Loji Rawatan Kumbahan 1 (LRK\# 1) dan 2 (LRK\#2) (Sumber: Google Earth)

Seterusnya, loji rawatan kumbahan kedua (LRK\#2) pula telah dipilih sebagai perbandingan dengan kawasan kajian pertama. Selain permonitoran parameter kimia COD dan $\mathrm{NH}_{3}-\mathrm{N}$, sampel air sisa domestik di LRK\#2 juga dianalisis dengan beberapa parameter kimia yang lain seperti nitrogen nitrat $\left(\mathrm{NO}_{3}-\right.$ N), jumlah pepejal terampai (TSS), $\mathrm{pH}$, ortofosfat $\left(\mathrm{PO}_{4}{ }^{3-}\right)$, kekonduksian, kekeruhan, jumlah nitrogen kjeldahl (TKN), dan elemen logam berat, iaitu $\mathrm{Cd}, \mathrm{Cr}, \mathrm{Cu}, \mathrm{Ni}, \mathrm{Pb}$, \& Zn. Loji rawatan LRK\#2 ini mempunyai saiz PE yang lebih besar, iaitu melebihi dua kali ganda saiz LRK\# 1, iaitu 150,000 dan juga masih terletak di kawasan sekitar Lembah Klang dengan jarak antara dua lokasi LRK ini adalah sejauh $35 \mathrm{~km}$. Kekerapan pensampelan bagi LRK\#2 dilakUkan secara mingguan selama tiga bulan, iaitu dari bulan Julai 2020 hingga September 2020 .

\subsection{Pensampelan}

Kajian ini telah mengambil air sisa influen dengan menggunakan mesin pensampelan automatik model ISCO 6700 (Teledyne ISCO, USA) dengan tetapan setiap satu jam selama tempoh 24 jam. Sebanyak 500 $\mathrm{mL}$ sampel diambil secara automatik ke dalam botol polietilena yang terlebih dahulu dibersihkan dengan menggunakan sabun, dibilas dengan menggunakan air suling, dan dikeringkan dengan menggunakan oven. Selepas lengkap 24 jam, sampel air sisa dikeluarkan dari alat pensampelan dan segera dibawa ke makmal untuk tujuan analisis. Semua sampel dianalisis pada hari yang sama bagi COD, $\mathrm{NO}_{3}-\mathrm{N}$, dan $\mathrm{NH}_{3}-\mathrm{N}$, manakala uji kaji yang seterusnya akan dilengkapkan dalam tempoh maksimum 48 jam dan disimpan di bawah suhu $4^{\circ} \mathrm{C}$.

\subsection{Analisis}

Kaedah analisis yang dilakukan berpandukan garis panduan American Public Health Association (APHA)[23]. Kaedah refluks tertutup daripada pembekal HACH (method 8000) digunakan untuk menentukan COD, manakala kepekatan $\mathrm{NH}_{3}-\mathrm{N}$ pula diukur dengan menggunakan kaedah elektrod pemilih ion (ISE) dengan menyediakan sebanyak $12.5 \mathrm{~mL}$ air sampel dan ditambah dengan $250 \mu \mathrm{L}$ pelaras-pH kekuatan ion beralkali (ISA) (Thermo-fisher, UK). Seterusnya, kepekatan nitrat nitrogen $\left(\mathrm{NO}_{3}-\mathrm{N}\right)$ menggunakan kaedah daripada pembekal $\mathrm{HACH}$ (method 4500), $\mathrm{pH}$ menggunakan meter pH (Eutech $\mathrm{pH}-450)$, kekeruhan menggunakan meter kekeruhan (Eutech TN-100), kekonduksian menggunakan meter konduktiviti (Eutech Con-450), dan TSS menggunakan 
kaedah APHA Method 2450 melalui penurasan air sampel dan pengeringan pada suhu $103^{\circ} \mathrm{C}$ hingga $105^{\circ} \mathrm{C}$. Sementara itu, kandungan logam berat pula ditentukan dengan menggunakan kaedah Spektrometer Jisim-Gandingan Plasma Teraruh (ICPMS). Semua analisis air sampel telah diulang sebanyak dua kali sebagai kaedah replikasi. Jadual 4 menunjukkan ringkasan parameter dan kaedah analisis yang digunakan.

Jadual 4 Parameter dan kaedah analisis pencirian air sisa domestik perbandaran

\begin{tabular}{ll}
\hline Parameter & Kaedah Analisis \\
\hline permintaan oksigen kimia, & Spektrofotometer (HACH - \\
COD & Method 8000) \\
Nitrogen-ammonia, $\mathrm{NH}_{3}-\mathrm{N}$ & Meter ISE (pH450, Eutech) \\
Nitrogen-nitrat, $\mathrm{NO}_{3}-\mathrm{N}$ & APHA, 2012- Method 4500 \\
$\mathrm{pH}$ & Meter $\mathrm{pH}$ (pH450, Eutech) \\
Kekeruhan & Meter kekeruhan (TN-100, \\
& Eutech) \\
Kekonduksian & Meter konduktiviti (Con 450, \\
Jumlah pepejal terampai, & Eutech) \\
TSS & APHA, 2012- Method 2540 \\
Jumlah nitrogen kjeldahl, & APHA, 2012- Method 4500- \\
TKN & Norg B \\
Ortofosfat, PO ${ }_{4}^{3-}$ & Spektrofotometer (HACH- \\
Analisa logam (Cd, Cr, & Method 8190) \\
Cu,Ni, Pb \& $\mathrm{Zn)}$ & Spektrometer Jisim- \\
\hline
\end{tabular}

\subsection{DAPATAN DAN PERBINCANGAN}

\subsection{Kepekatan COD bagi Influen}

Terdapat pelbagai campuran bahan organik dan bahan pencemar yang terkandung dalam air sisa domestik. Ternyata sukar bagi menentukan kepekatan bagi setiap satu jenis daripada bahan pencemar ini. Oleh hal yang demikian, parameter kepekatan COD ternyata memadai untuk menentukan tahap awal pencemaran organik, manakala kandungan $\mathrm{NH}_{3}-\mathrm{N}$ pula menunjukkan tahap pencemaran tidak organik dalam air sisa. Oleh itu, kajian permulaan penentuan kekuatan air sisa di influen loji rawatan kumbahan dimulakan dengan kepekatan COD dan $\mathrm{NH}_{3}-\mathrm{N}$ di lokasi kajian pertama, LRK\#1. Keputusan analisis ditunjukkan menerusi Rajah 2, iaitu bagi corak kepekatan COD pada tahun 2019 hingga 2020. Secara umumnya, terdapat perbezaan kepekatan yang agak ketara pada waktu-waktu tertentu dalam tempoh 24 jam yang jelas menunjukkan waktu puncak yang tinggi dan waktu aliran rendah. Perbandingan corak kepekatan bagi 10 hari pensampelan ini juga menunjukkan kepekatan COD adalah konsisten, iaitu berkepekatan yang turun naik dan mempunyai dua waktu puncak jelas pada waktu yang sama, iaitu pagi sekitar jam 8:00 hingga 10:00 dan waktu malam, iaitu jam 19:00 hingga 21:00. Selain itu, kepekatan yang landai dapat dilihat pada waktu pagi (jam 0:00 hingga 6:00) dan waktu petang (jam 13:00 hingga 18:00) menunjukkan penggunaan air yang rendah pada waktu ini. Kepekatan COD yang paling tinggi ialah $468 \mathrm{mg} / \mathrm{L}$ pada jam 9:00 pagi dan yang paling rendah ialah 109 mg/L pada jam 4:00 pagi.

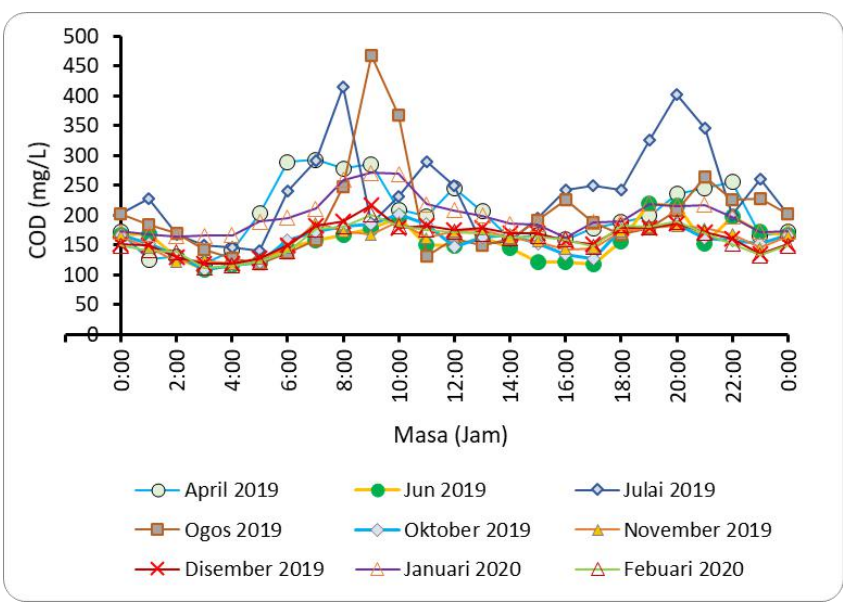

Rajah 2 Kepekatan COD bagi influen LRK\# 1 secara bulanan dari April 2019 sehingga Februari 2020

Seterusnya, kepekatan COD di LRK\#2 ditunjukkan menerusi Rajah 3. Berbeza dengan corak kepekatan COD di LRK\#1, LRK\#2 tidak menunjukkan graf yang konsisten pada setiap kali pensampelan. Kepekatan COD menunjukkan corak yang turun naik dan tidak sama sepanjang hari jika dibandingkan dengan kepekatan COD di LRK\#l yang menunjukkan corak turun naik pada waktu yang sama. Keadaan ini menunjukkan bahawa pusat rawatan air sisa bagi saiz PE yang lebih tinggi tidak mempunyai kadar turun naik yang tinggi jika dibandingkan dengan PE yang lebih rendah, selari dengan kajian Raboni (2014) [24] yang mendapati bahawa loji rawatan bagi penduduk yang lebih rendah akan mempunyai faktor kepekatan turun naik yang lebih tinggi jika dibandingkan dengan loji rawatan yang bersaiz lebih besar. Selain itu, julat kepekatan COD bagi influen di LRK\#2 adalah antara $108 \mathrm{mg} / \mathrm{L}$ hingga $1100 \mathrm{mg} / \mathrm{L}$ yang jelas menunjukkan bahawa kepekatan yang rendah adalah pada jam 1:00, manakala kepekatan yang tinggi pula adalah pada jam 10:00. 


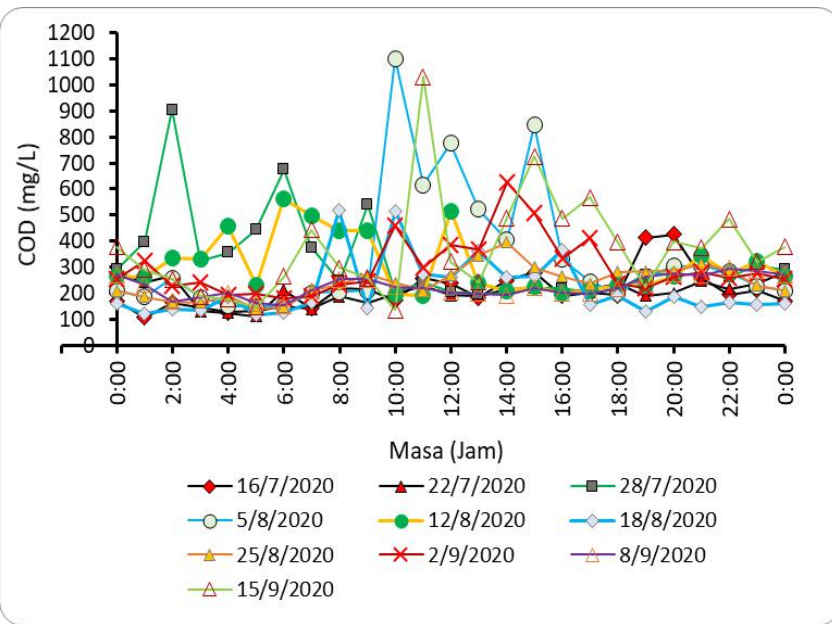

Rajah 3 Kepekatan COD bagi influen LRK\#2 secara mingguan dari 16/7/2020 sehingga 15/9/2020

Purata kepekatan COD bagi kedua-dua lokasi, baik LRK\# 1 mahupun LRK\#2 telah dikira secara purata dan diplotkan dalam graf seperti yang boleh dilihat menerusi Rajah 4. Secara umumnya, kepekatan COD bagi LRK\#2 adalah nyata lebih tinggi jika dibandingkan dengan LRK\# 1 yang jelas menunjukkan bahawa jumlah PE bagi LRK\#2 melebihi dua kali ganda saiz PE bagi LRK\# 1 mempengaruhi kepekatan organik dalam air sisa influen bagi loji rawatan ini. Selain itu, corak kepekatan COD bagi LRK\#2 menunjukkan corak turun naik yang tidak sekata jika dibandingkan dengan LRK\# 1 yang menunjukkan lengkung plot kenaikan dan penurunan COD yang lebih licin selain menunjukkan waktu puncak dan waktu bukan puncak penggunaan air bagi komuniti. Secara keseluruhannya, kepekatan COD bagi keduadua lokasi kajian ini berada dalam kategori rendah (berkepekatan rendah) seperti yang ditunjukkan menerusi Jadual 8 (nilai tipikal air sisa domestik) yang jelas menunjukkan bahawa COD kepekatan di bawah $500 \mathrm{mg} / \mathrm{L}$ berada dalam kategori rendah, manakala antara 750 hingga $1200 \mathrm{mg} / \mathrm{L}$ pula berada dalam kategori sederhana dan kategori tinggi bagi melebihi $1200 \mathrm{mg} / \mathrm{L}$ [23].

Berdasarkan nilai reka bentuk bagi loji rawatan kumbahan yang digunakan, iaitu Garis Panduan Industri Pembetungan Malaysia (MSIG)[1], purata setiap jam kepekatan COD terhadap kedua-dua lokasi ini bagi tempoh 24 jam masih berada di bawah paras reka bentuk minimum, iaitu $500 \mathrm{mg} / \mathrm{L}$. Perbandingan kepekatan influen COD bagi kajian ini dan beberapa lokasi lain, iaitu Australia[26], Greece[27], Kuala Lumpur, Malaysia[28], dan Bangalore[29] ditunjukkan menerusi Jadual 5. Berdasarkan perbandingan ini, didapati bahawa purata nilai COD yang diperoleh di lokasi kajian ini adalah setara dengan kajian-kajian yang lain yang mempunyai julat antara $121 \pm 27$ (Australia) hingga 390 \pm 48 (Bangalore).

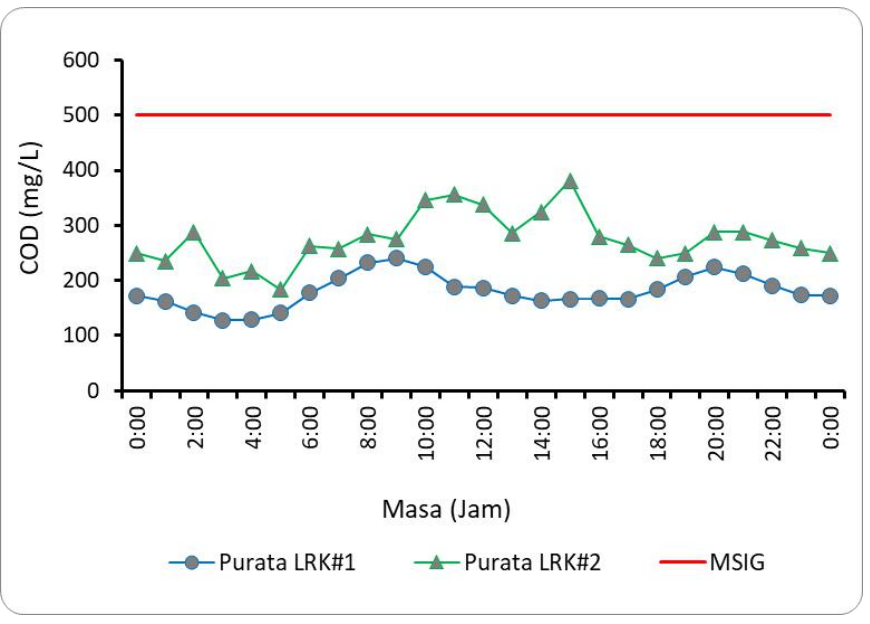

Rajah 4 Purata kepekatan COD di LRK\# 1 dan LRK\#2. Garis lurus merah menunjukkan nilai COD rekabentuk mengikut Garis Panduan Industri Pembetungan Malaysia (MSIG)

Jadual 5 Perbandingan kepekatan COD dalam influen loji rawatan kumbahan

\begin{tabular}{ll}
\hline \multicolumn{1}{c}{ Lokasi kajian } & \multicolumn{1}{c}{ COD (mg/L) } \\
\hline Kajian ini LRK\# 1 & $180.9 \pm 37.7$ \\
Kajian ini LRK\#2 & $275.0 \pm 120.5$ \\
Australia & $121 \pm 27$ \\
Greece & $330 \pm 79$ \\
Kuala Lumpur, Malaysia & $126 \pm 125.9$ \\
Bangalore & $390 \pm 48$ \\
\hline
\end{tabular}

\subsection{Kepekatan $\mathrm{NH}_{3}-\mathrm{N}$ dalam influen}

Kandungan ammonia dalam air sisa tidak akan disingkirkan secara sepenuhnya daripada air sisa secara semula jadi. Oleh hal yang demikian, kepekatannya sememangnya penting untuk diketahui dalam air sisa bagi menentukan kesesuaian rawatan yang diperlukan. Dalam konteks kajian ini, berdasarkan ciri kepekatan ammonia nitrogen $\left(\mathrm{NH}_{3}-\mathrm{N}\right)$ di lokasi kajian pertama, LRK\# 1 menunjukkan corak kepekatan yang konsisten dan hampir sama bagi setiap kali pensampelan seperti yang ditunjukkan menerusi Rajah 5. Kepekatan $\mathrm{NH}_{3}-\mathrm{N}$ yang didapati adalah antara 16 hingga $52 \mathrm{mg} / \mathrm{L}$ dan berdasarkan plot yang diperoleh, satu waktu puncak dapat dilihat dengan jelas, iaitu pada waktu pagi sekitar jam 10:00. Seterusnya, kepekatan $\mathrm{NH}_{3}-\mathrm{N}$ didapati rendah dari jam 0:00 hingga jam 5:00 dan dari jam 14:00 hingga jam 18:00 yang jelas menunjukkan kadar penggunaan air yang rendah oleh komuniti pada waktu-waktu tersebut. 


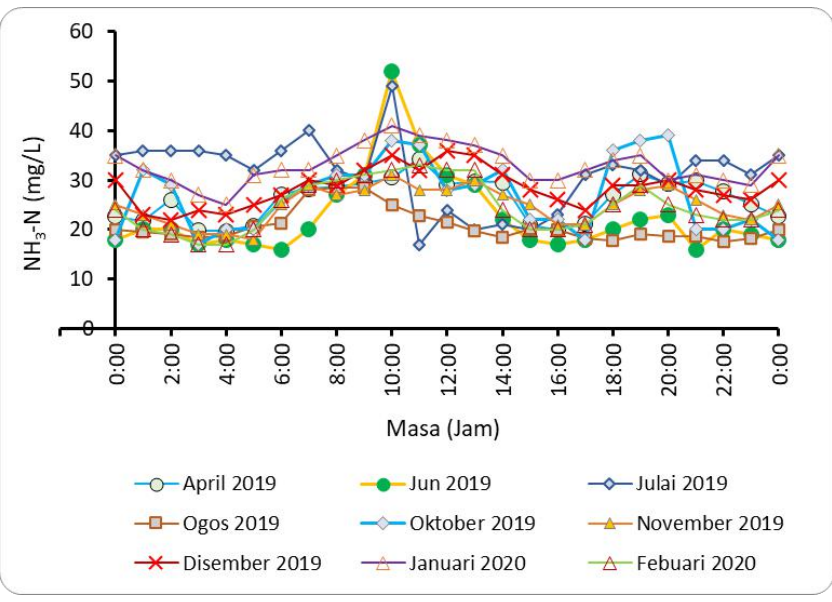

Rajah 5 Kepekatan $\mathrm{NH}_{3}-\mathrm{N}$ di influen LRK\# 1 secara bulanan dari Januari 2019 sehingga Februari 2020

Kepekatan $\mathrm{NH}_{3}-\mathrm{N}$ bagi LRK\#2 ditunjukkan menerusi Rajah 6. Sebagaimana corak $\mathrm{NH}_{3}-\mathrm{N}$ dalam LRK\# 1, LRK\#2 ini juga menunjukkan corak yang sama dan lebih konsisten setiap kali pensampelan dan menunjukkan kepekatan yang rendah pada waktu yang sama, iaitu dari jam 0:00 hingga jam 5:00 dan dari jam 14:00 hingga jam 18:00. Selain itu, LRK\#2 juga mempunyai satu waktu puncak yang sama yang lebih jelas seperti ditunjukkan pada plot dalam Rajah 6, iaitu waktu pagi sekitar jam 11:00 dan nilai kepekatan NH3$\mathrm{N}$ antara $4 \mathrm{mg} / \mathrm{L}$ hingga $43.4 \mathrm{mg} / \mathrm{L}$. Walaupun LRK\#2 merupakan loji rawatan yang lebih besar, namun didapati bahawa nilai julat kepekatan ammonia dalam air influen adalah setara dengan lokasi pertama walaupun mempunyai saiz rawatan yang lebih kecil.

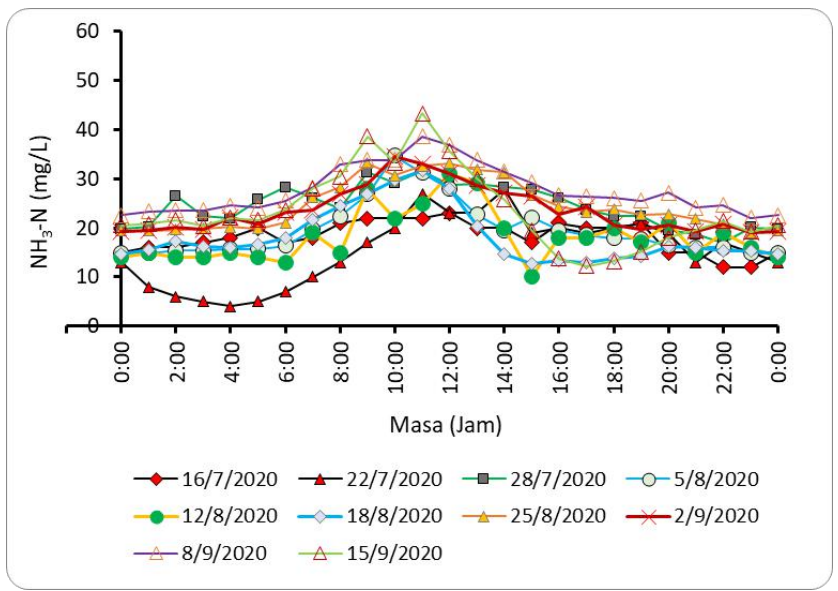

Rajah 6 Kepekatan $\mathrm{NH}_{3}-\mathrm{N}$ di influen LRK\#2 secara mingguan dari bulan Julai 2020 sehingga September 2020

Seterusnya, purata kepekatan $\mathrm{NH}_{3}-\mathrm{N}$ bagi keduadua LRK telah dikira dan diplotkan dalam satu graf yang sama seperti yang ditunjukkan menerusi Rajah 7. Secara keseluruhannya, perbandingan kepekatan $\mathrm{NH}_{3} \mathrm{-N}$ terhadap dua lokasi LRK ini menunjukkan perbezaan saiz PE tidak mempengaruhi kepekatan ammonia nitrogen dalam influen air sisa. Hal ini dibuktikan dengan nilai purata kepekatan $\mathrm{NH}_{3}-\mathrm{N}$ di LRK\# 1 adalah lebih tinggi sedikit jika dibandingkan dengan LRK\#2. Julat kepekatan LRK\#1 adalah antara 21.4 hingga $33.53 \mathrm{mg} / \mathrm{L}$, manakala LRK\#2 pula menunjukkan julat antara 17.26 hingga $31.63 \mathrm{mg} / \mathrm{L}$. Selain itu, waktu puncak bagi kedua-dua lokasi ini juga turut menunjukkan satu waktu yang sama, iaitu antara waktu pagi dari jam 10:00 hingga ke jam 11:00 yang menunjukkan corak penggunaan air yang hampir sama bagi komuniti ini. Namun begitu, LR\# 1 menunjukkan waktu puncak yang kedua dengan peningkatan yang lebih nyata pada jam 19:00 dengan kepekatan sebanyak $28.4 \mathrm{mg} / \mathrm{L}$.

Secara keseluruhannya, kepekatan $\mathrm{NH}_{3} \mathrm{~N}$ bagi kedua-dua lokasi kajian ini berada dalam kategori rendah dan sederhana seperti nilai yang ditunjukkan menerusi Jadual 8, iaitu $\mathrm{NH}_{3}-\mathrm{N}$ berkepekatan di bawah $20 \mathrm{mg} / \mathrm{L}$ dan berada dalam kategori rendah antara 20 hingga $45 \mathrm{mg} / \mathrm{L}$ ada sederhana dan tinggi bagi melebihi $75 \mathrm{mg} / \mathrm{L}$ [25]. Seterusnya, perbandingan dengan nilai reka bentuk loji sebanyak $30 \mathrm{mg} / \mathrm{L}$ menunjukkan kepekatan $\mathrm{NH}_{3}-\mathrm{N}$ melebihi nilai minimum reka bentuk loji ketika waktu puncak dan ketika aliran perlahan kepekatan $\mathrm{NH}_{3}-\mathrm{N}$ berada di bawah nilai reka bentuk. Perbandingan nilai purata kepekatan $\mathrm{NH}_{3}-\mathrm{N}$ loji kajian ini juga dibandingkan dengan beberapa lokasi kajian yang lain, iaitu Australia[26], Greece[27], dan Johor, Malaysia[30] dan Kuala Lumpur, Malaysia[28]. Didapati bahawa kepekatan $\mathrm{NH}_{3}-\mathrm{N}$ di kajian ini adalah setara dengan nilai kepekatan $\mathrm{NH}_{3}-\mathrm{N}$ di lokasi-lokasi yang lain dengan julat antara 12.8 \pm 3.6 (Kuala Lumpur, Malaysia) hingga 48.2 \pm 12 (Greece).

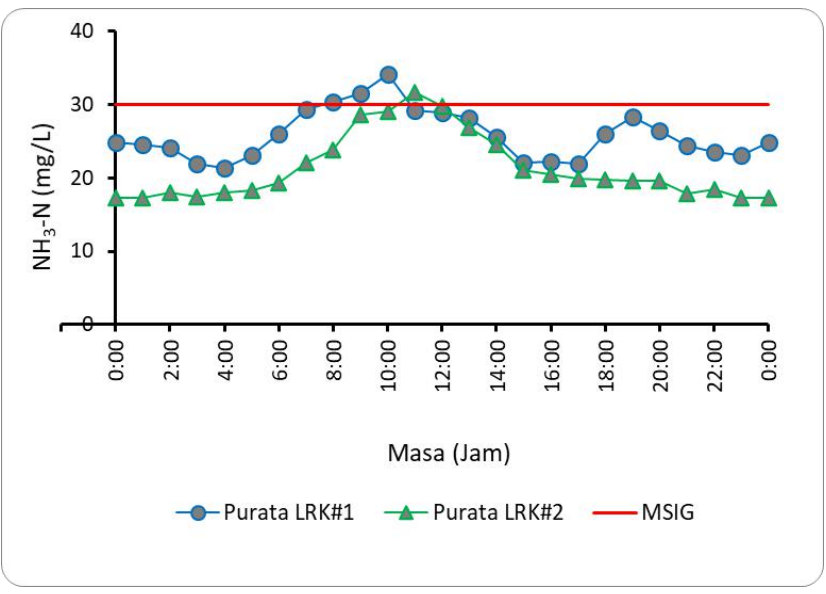

Rajah 7 Purata kepekatan $\mathrm{NH}_{3}-\mathrm{N}$ bagi LRK\# 1 dan LRK\#2 
Jadual 6 Perbandingan kepekatan COD dalam influen loji rawatan kumbahan

\begin{tabular}{ll}
\hline \multicolumn{1}{c}{ Lokasi kajian } & \multicolumn{1}{c}{$\mathbf{N H}_{3}-\mathbf{N}(\mathbf{m g} / \mathbf{L})$} \\
\hline Kajian ini LRK\# 1 & $25.8 \pm 5.3$ \\
Kajian ini LRK\#2 & $21.3 \pm 4.7$ \\
Australia & $39.4 \pm 9.7$ \\
Greece & $48.2 \pm 12$ \\
Johor, Malaysia & $39.99 \pm 2.54$ \\
Kuala Lumpur malaysia & $12.8 \pm 3.6$ \\
\hline
\end{tabular}

\subsection{Ciri-Ciri Fiziko-Kimia dalam Air Sisa Perbandaran}

Seterusnya, selain penentuan ciri COD dan $\mathrm{NH}_{3}-\mathrm{N}$, parameter fiziko-kimia yang lain juga turut diuji terhadap air sisa domestik di LRK\#2. Sehubungan dengan itu, sebanyak tiga kali pensampelan dan analisis telah dilakukan untuk mendapatkan nilai purata bagi setiap parameter tersebut. Keputusan analisis adalah seperti yang ditunjukkan menerusi Jadual 7. Nilai $\mathrm{pH}$ yang diperoleh bagi influen adalah antara 6.90 hingga 7.15 dengan nilai puratanya $7.00 \pm 0.10$ yang jelas menunjukkan nilai ini seiring dengan nilai $\mathrm{pH}$ yang biasa dikesan bagi air sisa domestik, iaitu antara 6.8 hingga 8.3 [19]. Seterusnya, suhu air sisa pula dibaca secara in situ di lapangan dan bacaannya adalah antara 28.1 hingga $29.7^{\circ} \mathrm{C}$ dengan purata suhu $29.00 \pm 0.67^{\circ} \mathrm{C}$.

Bacaan pepejal terampai penting bagi mengukur kepekatan bahan terampai dalam air sisa memandangkannya akan menentukan reka bentuk tangki mendapan dan seterusnya akan memberikan petunjuk terhadap keupayaan keperluan kawalan enap cemar bagi kolam rawatan LRK. Bagi mengetahui pepejal terampai dalam air sisa, jumlah pepejal terampai (TSS) telah diukur dan keputusannya menunjukkan TSS dalam influen adalah antara 175.75 hingga $218 \mathrm{mg} / \mathrm{L}$ dan nilai puratanya 197.19 $\pm 7.06 \mathrm{mg} / \mathrm{L}$. Sementara itu, nilai kepekatan jumlah nitrogen kjeldahl (TKN) pula adalah antara 27 hingga $48 \mathrm{mg} / \mathrm{L}$ dengan nilai puratanya $32.00 \pm 11.58 \mathrm{mg} / \mathrm{L}$. Parameter fosforus juga merupakan sumber nutrien dalam proses pengoksidaan dalam rawatan kumbahan. Dalam konteks kajian ini, nilai kepekatan fosforus dibaca dalam bentuk ortofosfat $\left(\mathrm{PO}_{4}{ }^{3-}\right)$ dan keputusannya adalah antara 7 hingga $9 \mathrm{mg} / \mathrm{L}$ dengan purata $8.00 \pm$ $0.82 \mathrm{mg} / \mathrm{L}$.

Seterusnya, nilai kekeruhan bagi influen adalah antara 100 hingga 129 NTU dengan purata $110.47 \pm 13.16$ NTU, manakala kekonduksiannya pula adalah antara 356 hingga $540 \mu S / c m$ dengan purata $432 \pm 78.45 \mu \mathrm{S} / \mathrm{cm}$. Penilaian ciri fiziko-kimia bagi influen LRK\#2 dibandingkan dengan nilai tipikal kepekatan air sisa seperti yang boleh dilihat menerusi Jadual 4 yang menunjukkan influen air sisa perbandaran berada dalam kategori rendah dan sederhana. Nilai $\mathrm{pH}$ dan TSS berada dalam kategori rendah, manakala ortofosfat dan konduktiviti pula berada dalam kategori sederhana.
Jadual 7 Ringkasan hasil nilai purata bagi parameter fizikokimia influen LRK\#2

\begin{tabular}{|c|c|c|c|c|}
\hline Parameter & $\begin{array}{c}\text { Sampel } \\
1\end{array}$ & $\begin{array}{c}\text { Sampel } \\
\mathbf{2}\end{array}$ & $\begin{array}{c}\text { Sampel } \\
3\end{array}$ & Purata \\
\hline $\mathrm{pH}$ & 6.90 & 6.97 & 7.15 & $7.00 \pm 0.10$ \\
\hline Suhu $\left({ }^{\circ} \mathrm{C}\right)$ & 29.20 & 29.70 & 28.10 & $29 \pm 0.67$ \\
\hline TSS (mg/L) & 175.75 & 218.00 & 198.00 & $197.19 \pm 7.06$ \\
\hline $\begin{array}{l}\text { Nitrat } \\
\text { (mg/L) }\end{array}$ & 4.67 & 4.94 & 6.28 & $5.30 \pm 0.70$ \\
\hline TKN (mg/L) & 48 & 21 & 27 & $32.00 \pm 1.58$ \\
\hline $\begin{array}{l}\text { Ortofosfat } \\
\text { (mg/L) }\end{array}$ & 8 & 9 & 7 & $8.00 \pm 0.82$ \\
\hline $\begin{array}{l}\text { Kekeruhan } \\
\text { (NTU) }\end{array}$ & 129 & 100 & 103 & $110.47 \pm 3.16$ \\
\hline $\begin{array}{l}\text { Konduktiviti } \\
(\mu \mathrm{S} / \mathrm{cm})\end{array}$ & 540 & 400 & 356 & $432 \pm 78.45$ \\
\hline
\end{tabular}

Jadual 8 Nilai tipikal air kumbahan [23]

\begin{tabular}{llll}
\hline Parameter & Tinggi & Sederhana & Rendah \\
\hline $\mathrm{COD}(\mathrm{mg} / \mathrm{L})$ & 1200 & 750 & 500 \\
$\mathrm{NH}_{3}-\mathrm{N}(\mathrm{mg} / \mathrm{L})$ & 75 & 45 & 20 \\
Ortofosfat $(\mathrm{mg} / \mathrm{L})$ & 15 & 10 & 4 \\
$\mathrm{TSS}(\mathrm{mg} / \mathrm{L})$ & 600 & 400 & 250 \\
$\mathrm{pH}$ & 8.0 & 7.5 & 7.0 \\
Kekonduksian $(\mu \mathrm{S} / \mathrm{cm})$ & 1200 & 1000 & 700 \\
\hline
\end{tabular}

\subsection{Kandungan Logam Berat dalam Influen}

Pelbagai jenis logam berat ditemui dalam badan air dan dikenal pasti ada antaranya dalam kategori yang bertoksik dan kasinorgen kepada sumber hidupan [31, 32]. Berdasarkan dapatan kajian daripada kajian lepas, didapati bahawa logam berat yang ditemui dalam air berpunca daripada luahan air kumbahan, enapcemar kumbahan, dan aktiviti pertanian dan perindustrian $[15,33,34]$. Antara elemen logam berat yang dikenal pasti sebagai toksik kepada tanah, air, dan sumber makanan ialah arsenic (As), cadmium (Cd), kromium (Cr), tembaga (Cu), merkuri (Hg), mangan (Mn), nikel (Ni), plumbum (Pb), dan zink ( $\mathrm{Zn})$ $[31,35,36]$. Oleh hal yang demikian, kajian ini dapat mengesan nilai kepekatan logam berat bagi elemen $\mathrm{Cd}, \mathrm{Cr}, \mathrm{Cu}, \mathrm{Ni}, \mathrm{Pb}$, dan $\mathrm{Zn}$ seperti yang ditunjukkan menerusi Jadual 9. Berdasarkan perbandingan nilai kepekatan logam yang diperoleh, elemen $\mathrm{Zn}$ mencatatkan kepekatan yang tertinggi, iaitu $34.828 \pm 21.6 \mu \mathrm{g} / \mathrm{L}$, manakala Cd pula mempunyai

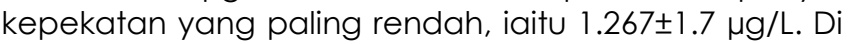
samping itu, elemen logam yang lain juga turut

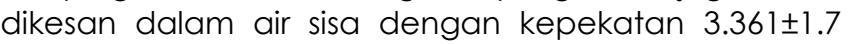
$\mu \mathrm{g} / \mathrm{L}$ bagi $\mathrm{Ni}, 4.255 \pm 2.0 \mu \mathrm{g} / \mathrm{L}$ bagi $\mathrm{Cr}, 7.079 \pm 5.0 \mu \mathrm{g} / \mathrm{L}$ bagi $\mathrm{Pb}$, dan $8.676 \pm 5.0 \mu \mathrm{g} / \mathrm{L}$ bagi $\mathrm{Cu}$. Seterusnya, dengan purata kepekatan yang diperoleh, perbandingan dengan kepekatan logam dalam kajian Chirila et al. (2014) [37] dan Drozdova et al., 2018 [38] ditunjukkan menerusi Jadual 9. Didapati juga bahawa kandungan Zn merupakan yang tertinggi 
ditemui dalam air sisa, iaitu antara 30 hingga $1000 \mu \mathrm{g} / \mathrm{L}$ [37] dan 114 hingga $403 \mu \mathrm{g} / \mathrm{L}$ [38], manakala seperti kajian ini pula, kepekatan $\mathrm{Cd}$ dikesan paling rendah dalam air sisa, iaitu 0.25 hingga $3 \mu \mathrm{g} / \mathrm{L}$ [37] dan kurang $4 \mu \mathrm{g} / \mathrm{L}[38]$.

Nilai kepekatan logam yang diperoleh juga turut dibandingkan dengan nilai kepekatan tipikal logam dalam air sisa kumbahan seperti yang boleh dilihat menerusi Jadual 10 yang jelas menunjukkan bahawa logam Cd sahaja dalam kategori sederhana, manakala logam-logam lain pula adalah dalam kategori rendah. Nilai kepekatan logam yang rendah menunjukkan sampel berpunca daripada kumbahan domestik sahaja dan bukan campuran daripada air sisa industri. Kehadiran logam daripada kumbahan domestik berpunca dari kawasan persekitaran dan gaya hidup penduduk kawasan kajian ini. Seperti yang dilaporkan oleh Agoro (2020)[15]; Ab Razak (2016)[39]; \& Aonghusa \& Gray (2002)[40], logam dibawa ke loji kumbahan melalui pelbagai sumber seperti makanan, air paip, sabun mandi, detergen, kosmetik, peluh, dan habuk.

Jadual 9 Perbandingan kepekatan logam berat dalam air sisa influen

\begin{tabular}{lccc}
\hline $\begin{array}{l}\text { Logam } \\
\text { berat }\end{array}$ & $\begin{array}{l}\text { Kajian ini, } \\
\text { purata }(\boldsymbol{\mu g} / \mathbf{L})\end{array}$ & $\begin{array}{l}{[\mathbf{3 7}]} \\
(\boldsymbol{\mu g} / \mathbf{L})\end{array}$ & $\begin{array}{l}{[\mathbf{3 8}]} \\
(\mathbf{m i n} .- \text { maks. }) \\
(\boldsymbol{\mu g} / \mathbf{L})\end{array}$ \\
\hline $\mathrm{Cd}$ & $1.267 \pm 1.7$ & $0.25-3.00$ & $<-4.0$ \\
$\mathrm{Cr}$ & $4.255 \pm 2.0$ & $3.5-50.00$ & $1.909-4.645$ \\
$\mathrm{Cu}$ & $8.676 \pm 5.0$ & $1-20$ & $13.0-65.0$ \\
$\mathrm{Ni}$ & $3.361 \pm 1.7$ & $5-50$ & $<-16.0$ \\
$\mathrm{~Pb}$ & $7.079 \pm 5.0$ & $2.5-50$ & $1-38.0$ \\
$\mathrm{Zn}$ & $34.828 \pm 21.6$ & $30-1000$ & $114-403$ \\
\hline \multicolumn{4}{c}{} \\
& < kepekatan dibawah had pengesanan $(<1 \mu \mathrm{g} / \mathrm{L})$
\end{tabular}

Jadual 10 Nilai tipikal logam berat dalam air kumbahan ( $\mu \mathrm{g} / \mathrm{L})$ [23]

\begin{tabular}{lccc}
\hline Parameter & Tinggi & Sederhana & Rendah \\
\hline $\mathrm{Cd}$ & 4 & 2 & 1 \\
$\mathrm{Cr}$ & 40 & 25 & 10 \\
$\mathrm{Cu}$ & 100 & 70 & 30 \\
$\mathrm{Ni}$ & 40 & 25 & 10 \\
$\mathrm{~Pb}$ & 80 & 60 & 25 \\
$\mathrm{Zn}$ & 300 & 200 & 100 \\
\hline
\end{tabular}

\subsection{KESIMPULAN}

Sebagai kesimpulannya, kualiti air sisa domestik di kawasan perbandaran di lokasi kajian bersifat turun naik secara temporal bagi parameter COD dan $\mathrm{NH}_{3}-\mathrm{N}$, namun sedikit tidak konsisten terhadap corak COD di LRK\#2. Kepekatan influen bagi kedua-dua lokasi juga adalah dalam kategori rendah dan berkepekatan sederhana pada waktu puncak dengan julat kepekatan COD antara 108 hingga $1100 \mathrm{mg} / \mathrm{L}$, manakala kepekatan $\mathrm{NH}_{3}-\mathrm{N}$ pula adalah antara 4 hingga $52 \mathrm{mg} / \mathrm{L}$. Parameter fiziko-kimia juga menunjukkan tahap kekonduksian, kekeruhan, jumlah pepejal terampai (TSS), nitrogen nitrat $\left(\mathrm{NO}_{3}-\mathrm{N}\right)$, dan elemen logam berat (Cadmium, Kromium, Tembaga, Nikel, Plumbum dan Zink) adalah dalam kumpulan yang rendah dan sederhana. Walaupun ciri-ciri fizikokimia dalam air sisa kumbahan berciri rendah dan sederhana, namun kehadiran bahan-bahan pencemar ini ke dalam sungai dan badan air akan memberikan risiko kepada hidupan air, alam sekitar, dan komuniti. Oleh itu, bahan-bahan pencemar ini perlu dirawat sebelum dilepaskan ke badan air berdasarkan piawaian kualiti efluen yang telah ditetapkan.

\section{PENGHARGAAN}

Terima kasih kepada Jabatan Perkhidmatan Pembetungan, Kementerian Alam Sekitar dan Air, Indah Water Konsortium San. Bhd., Universiti Kebangsaan Malaysia dan Kementerian Pengajian Tinggi kerana membiayai penyelidikan ini di bawah geran fundamental FRGS/1/2018/TK01/UKM/02/4. penyelidikan

\section{Rujukan}

[1] MSIG (Malaysian Sewerage Industry Guidelines). 2009. IV(3): 29-34.

[2] Hanafiah, Z. M., Wan Mohtar, W. H. M., Hasan, H. A., Jensen, H. S., Abdullah, M. Z. \& Husain, H. 2019. Diversification of Temporal Sewage Loading Concentration in Tropical Climates. IOP Conference Series: Earth and Environmental Science. 264: 012026. DOI: 10.1088/1755-1315/264/1/012026.

[3] Watanabe, R., Harada, H., Yasui, H., Le, T. V. \& Fujii, S. 2019. Exfiltration and Infiltration Effect on Sewage Flow and Quality: A Case Study of Hue, Vietnam. Environmental Technology. 42(11): 1747-1757. DOI: 10.1080/09593330.2019.1680739.

[4] Zhang, H., Liu, C., Lee, C. T. \& Zhang, Z. 2019. A Novel Bio-film Wastewater Treatment System Using Encapsulated Microbes. Chemical Engineering Transactions. 72: 181-186. DOI: 10.3303/CET1972031

[5] Phanwilai, S., Noopan, P., Li, C. \&Choo, K. 2020. Effect of COD:N Ratio on Biological Nitrogen Removal using Full-scale Step-feed in Municipal Wastewater Treatment Plants. Sustainable Environment Research. 30: 24. DOI: 10.1 186/s42834-020-00064-6.

[6] Wang, J., Rong, H., Cao, Y. \& Zhang, C. 2020. Factors Affecting Simultaneous Nitrification and Denitrification (SND) in a Moving Bed Sequencing Batch Reactor (Mbsbr) System as Revealed by Microbial Community Structures. Bioprocess and Biosystems Engineering. 43: 1833-1846.

DOI: 10.1007/s00449-020-02374-w

[7] Yun, Y., Li, Z., Chen, Y., Saino, M., Cheng, S. \& Zheng, L. 2018. Elimination of Nitrate in Secondary Effluent of Wastewater Treatment Plants by $\mathrm{FeO}$ and $\mathrm{Pd}-\mathrm{Cu} /$ diatomite. Journal of Water Reuse \& Desalination. 8(1): 29-37. DOI: 10.2166/wrd.2016.122.

[8] Ward, M. H., Jones, R. R., Brender, J. D., Kok, T. M., Weyer, P. J., Nolan, B. T., Villanueva, C. M. \& Breda, S. G. 2018. Drinking Water Nitrate and Human Health: An Updated Review. Environmental Research and Public Health. 15: 1557. DOI: 10.3390/ijerph15071557.

[9] Griffiths, J. K. 2017. Waterborne Diseases International Encyclopedia of Public Health. Second Edition. 338-401.

[10] Liang, Y. Q., Annammala, K. V., Martin, P. Yong, E. L., Mazilamani, L. S. \& Najib, M. Z. M. 2020. Assessment of Physical-chemical Water Quality Characteristics and Heavy 
Metals Content of Lower Johor River, Malaysia. J. Environ. Treat. Tech. 8(3): 961-966.

[11] Ariffin, M. \& Sulaiman, S. N. M. 2015. Regulating Sewage Pollution of Malaysian Rivers and its Challenges. Procedia Environmental Sciences. 30: 168-173. DOI: 10.1016/j.proenv.2015.10.030.

[12] Sabeen, A. H., Ngadi, N., Noor, Z. Z., Raheem, A. B., Agovillal, F., Mohammed, A. A. \& Absulkarim, B. I. 2018. Characteristics of the Effluent Wastewater in Sewage Treatment Plants of Malaysian Urbans Areas. Chemical Engineering Transactions 63: 691-696. DOI: 10.3303/CET1863116.

[13] Martin, C. \& Vanrolleghem, P. A. 2014. Analysing, Completing, and Generating Influent Data for Wwtp Modelling: A Critical Review. Environmental Modelling \& Software. 60: 188-201.

DOI : 10.1016/j.envsoft.2014.05.008.

[14] Lee, S. H., Kang, H. J. \& Park, H. D. 2019. Influence of Influent Wastewater Communities on Temporal Variation of Activated Sludge Communities. Water Research. 73C: 132144. DOI: 10.1016/j.watres.2015.01.014.

[15] Agoro, M. A., Adeniji, A. O., Adefisoye, M. A. \& Okoh, O. O. 2020. Heavy Metals In Wastewater and Sewage Sludge from Selected Municipal Treatment Plants in Eastern Cape Province, South Africa. Water. 12: 2746. DOI: $10.3390 /$ w12102746.

[16] Messrouk, H. Hadj Mahammed, M. Touiil, Y. \& Amrane, A. 2014. Physico-chemical Characterization of Industrial Effluents From The Town of Ouargla (South East Algeria). Energy Procedia. 50: 255-262. DOI: 10.1016/j.egypro.2014.06.031.

[17] Muserere, S. T., Hoko, Z. \& Nhapi, I. 2014. Characterisation of Raw Sewage and Performance Assessment of Primary Settling Tanks at Firle Sewage Treatment Works, Harare, Zimbabwe. Physics and Chemistry of the Earth. 67-69: 226235. DOI : 10.1016/j.pce.2013.10.004.

[18] Kumar, V. \& Chopra, A. K. 2012. Monitoring of Physicochemical and Microbiological Characteristics of Municipal Wastewater at Treatment Plant, Haridwar City (Uttarakhand) India. Journal of Environmental Science and Technology. 5(2): 109-118.

DOI: 10.3923/jest.2012.109.118.

[19] Popa, P., Timofti, M., Voiculescu, M., Dragan, S., Trif, C. \& Georgescu, L. P. 2012. Study of Physico-Chemical Characteristics of Wastewater in an Urban Agglomeration in Romania. The Scientific World Journal. 2012: 549028. DOI: $10.1100 / 2012 / 549028$.

[20] Al-Enezi, G., Hamoda, M. F. \& Fawzi, N. 2004. Heavy Metals Content of Municipal Wastewater and Sludges in Kuwait. Journal of Environmental Science and Health, Part A: Toxic/Hazardous Substances and Environmental Engineering. 39(2): 397-407. DOI: 10.1081/ESE-120027531.

[21] Spanos, T., Ene, A., Styliani Patronidou, C. \& Xatzixristou, C. 2016. Temporal Variability of Sewage Sludge Heavy Metal Content from Greek Wastewater Treatment Plants. Ecol. Chem. Eng. S. 23(2): 271-283.

DOI : 10.1515/eces-2016-0019

[22] Wang, C., Hu, X., Chen, M. L. \& Wu, Y. H. 2005. Total Concentrations and Fractions of $\mathrm{Cd}, \mathrm{Cr}, \mathrm{Pb}, \mathrm{Cu}, \mathrm{Ni}$ and $\mathrm{Zn}$ in Sewage Sludge from Municipal and Industrial Wastewater Treatment. Journal of Hazardous Materials. 119 (1-3): 245-249. DOI :10.1016/j.jhazmat.2004.11.023.

[23] American Public Health Agency (APHA). 2012. Standard Methods for the Examination of Water and Wastewater. Edisi 22. New York.

[24] Raboni, M., Torretta, V., Viotti, P. \& Urbini, G. 2014. Pilot Experimentation with Complete Mixing Anoxic Reactors to
Improve Sewage Denitrification in Treatment Plants in Small Communities. Sustainability. 6: 112-122.

DOI: 10.3390/su6010112.

[25] Henze, M. \& Comeau, Y. 2008. Biological Wastewater Treatment: Principles, Modelling and Design. London, UK: IWA publishing. Chapter 3: 33-52.

[26] Cruz, H., Luckman, P., Seviour, T., Verstraete, W., Laycock, B. \& Pikaar, I. 2018. Rapid Removal of Ammonium From Domestic Wastewater Using Polymer Hydrogels. Scientific Report. 8: 2912.

DOI :10.1038/s41598-018-21204-4

[27] Sotirakou, E., Kladitis, G., Diamantis, N. \& Grigoropoulou, H. 1999. Ammonia and Phosphorus Removal in Municipal Wastewater Treatment Plant with Extended Aeration. Global Nest: The Int. J. 1: 47-53.

[28] Zhang, H., Liu, C., Lee, C. T. \& Zhang, Z. 2019. A Novel Bio-film Wastewater Treatment System using Encapsulated Microbes. Chemical Engineering Transactions. 72. DOI: 10.3303/CET1972031.

[29] Ravi Kumar, P., Pinto, L. B. \& Somashekar, R. K. 2010. Assessment of the Efficiency of Sewage Treatment Plants: A Comparative Study between Nagasandra and Mailasandra Sewage Treatment Plants. Kathmandu University Journal of Science, Engineering and Technology. 6(ii): 115-125.

[30] Hamdan, R., Ibrahim, I. I. \& Talib, A. N. A. 2015. Removal Ammonia Nitrogen from Domestic Wastewater using Vertical Aerated Limestone Filter. Applied Mechanics and Materials. 752-753: 232-237.

DOI: 10.4028/www.scientific.net/AMM.752-753.232.

[31] Ali, H., Khan, E. \& Ilahi, I. 2019. Environmental Chemistry and Ecotoxicology of Hazardous Heavy Metals: Environmental Persistence, Toxicity, and Bioaccumulation. J. Chem. 14. DOI : 10.1155/2019/6730305

[32] Simeonov, L. I., Kochubovski, M. V. \& Simeonova, B. G. 2011. Environmental Heavy Metal Pollution and Effects on Child Mental Development: Risk Assessment and Prevention Strategies. Eds. Springer: Berlin/Heidelberg, Germany. 344.

[33] Al-Musharafi, S. K., Mahmoud. I. Y. \& Al-Bahry, S. N. 2013. Heavy Metal Pollution from Treated Sewage Effluent. APCBEE Procedia. 5: 344-348. DOI: 10.1016/j.apcbee.2013.05.059.

[34] Hua, A. K. 2015. Kualiti Sumber Air di Malaysia: Satu Analisis. Malaysian Journal of Society and Space. $11(6)$ : 98-108

[35] Barakat, M. A. 2011. New Trends in Removing Heavy Metals from Industrial Wastewater. Arab. J. Chem. 4: 361-377. DOI: 10.1016/j.arabjc.2010.07.019.

[36] Khan, T., Muhammad, S., Khan, B. \& Khan, H. 2011. Investigating the Levels of Selected Heavy Metals in Surface Water of Shah Alam River (A Tributary of River Kabul, Khyber Pakhtunkhwa). J. Himal. Earth Sci. 44: 71-79.

[37] Chirila, G., Draghici, C. \& Puhacel, A. 2014. Total and Dissolved Metals Occurrence in Municipal Wastewater Treatment Plant Effluents Environmental. Engineering and Management Journal. 13(9): 2211-2218. DOI : 10.30638/eemj.2014.246

[38] Drozdova, J., Raclavska, H., Raclavsky, K. \& Skrobankova, H. 2018. Heavy Metals in Domestic Wastewater with Respect to Urban Population in Ostrava, Czech Republic. Water and Environment Journal. 0: 1-9. DOI : 10.1111/wej.12371.

[39] Abd Razak, A. R., Sunar, N. M., Alias, N. A., Gani, P. \& Subramaniam, M. 2016. Physiochemicals and Heavy Metal Removal from Domestic Wastewater via Phycoremediation. MATEC Web of Conferences. 47: 05003. DOI: $10.1051 /$ matecconf/20164705003.

[40] Aonghusa, C. N. \& Gray, N. F. 2002. Laundry Detergents as A Source of Heavy Metals in Irish Domestic Wastewater. J. Environ. Sci. Health. A37(1): 1-6. DOI: 10.1081/ESE-100108477. 